\title{
Measuring and interpreting emigration intentions of Hungarians
}

\author{
BeÁta SISKA-SZILASI, Tibor KÓRÓDI and PÉTER VADNAI
}

\begin{abstract}
International migration and problems associated with it attracted increasing attention among geographers. Hungary has been affected by various forms of international migration since the systemic changes of 1990 . This paper focuses on the emigration intentions of Hungarians, with special emphasis on regional differences, and age and gender dimensions. For the sake of analysis a questionnaire survey was carried out which resulted a database containing the answers of nearly 10 thousand respondents nationwide. During the survey we measured socio-economic status, age, gender, migrations intentions and previous migration records. Subjective quality of life factors, like happiness and satisfaction which may influence the migration intentions were also recorded. Based on the survey the main push factors of potential migration were defined. Our results confirm a more globalised pattern of migration intentions where women are at least as much involved in the process of preparation as men, and regions with good economic performance are equally affected as regions with economic hardship.
\end{abstract}

Keywords: international migration, labour mobility, Emigration Intention Index, post-socialism, Hungary

\section{Introduction}

Hungary has been strongly affected by international migration recently and problems associated with it. Although the Hungarian government and media predominantly focus on the issue of immigration, we should not ignore the growing number of Hungarians who left the country (emigrated) which also generates serious problems for the economy and society (Illés, S. 2008). The main objective of this paper is to examine the emigration intentions of Hungarians via empirical research methods. We would like to know which social groups and which geographic areas are the most affected by possible emigration, and what are the main triggering factors of migrants planning to leave the country. Though, the topic of emigration intentions among young people has been increasingly on the agenda in the media little has been said so far about the possible measurement of the process (MARIEN, A. 2015). During our research we carried out a questionnaire survey among Hungarian people regarding their migration intentions. Through this survey the following research questions are anwered:

1. Is emigration a selective process in Hungary?

2. Which social and demographic groups are the most affected?

3. What are the spatial differences of planned emigration within Hungary?

4. Are there any differences between rural and urban areas in this respect?

5. What are the main push factors behind the emigration intentions of people?

\section{The growing importance of international migration in Hungary}

The bulk of academic literature on migration focuses on models of international migration with special attention to push and pulls factors (Portes, A. and Böröcz, J. 1989). Most of these studies come to the conclusion that behind long-distance migration processes we usually find economic factors closely re-

\footnotetext{
${ }^{1}$ Institute of Geography and Geoinformatics, University of Miskolc, H-3515 Miskolc, Egyetemváros.

E-mails: ecobea@uni-miskolc.hu; ecokt@uni-miskolc.hu; ecovape@uni-miskolc.hu
} 
lated to employment opportunities and labour market conditions of the home country (DAYTON-Johnson, J. et al. 2009). International migration has been steadily growing in the world. In Europe the number of migrants was 64.1 million in 2005, while in North America 44.5 million. Increasing part of the European migration flows migration was stemming from East Central Europe (ECE), a geographical area that includes the former communistbloc countries (including Hungary) (RoBiLA, M. 2010). Another important issue often discussed in the literature is the growing complexity of migration. Previous concepts cannot always been used for explaining new forms of movements (SALT, J. 2001).

Countries can be predominantly sending (e.g. India, China) or receiving (e.g. USA, Australia) areas of international migration or as the case of Hungary demonstrates they can fit to both categories (LAKATOS-BÁLDY, Zs. 2011). International migration has several advantages for the host and the sending countries (NYÁrADI, G. 2011). The emigration intention is mostly determined by economic factors, but among young people the role of study abroad is also important (Hidasi, J. 2011). Focusing on youth migration the Active Youth in Hungary Research Group examined the migration intentions of Hungarian university students. The study focused on future plans of students about working abroad. The research found that while in 2013 about onethird of the Hungarian students planned emigration, by 2015 this ratio increased by 37 percent (Szabó, A. 2015).

Other case-studies on migration intentions of university students showed similar results. In a study about the University of Pécs, two-thirds of respondents planned international emigration (RoHR, A. 2012). The Identity Research Workgroup of National Minorities in Zenta (Serbia) made a similar research among high school students in 2010. Results showed that 25 percent of the students wanted to go abroad after graduation. In 2013 the Hungarian Demographic Research Institute (Népességtudományi Kutatóintézet, NKI) interviewed 1,500 peo- ple and calculated a 33 percent cumulative migration potential among young people. Similarly, the "Omnibusz" survey of TÁRKI Social Research Institute showed that in April, 2012, 39 percent of the young people (age between 18-29) wanted to go and stay abroad for a couple of weeks or months. Almost 40 percent wanted to work abroad for a couple of years and almost 25 percent of them planned permanent residence abroad.

Examining the emigration statistics of the EU countries based on data of the EUROSTAT, the emigration of Hungarians does not seem to be very high. 20 out of the 28 member states of the European Union have higher emigration rate than Hungary, including those more developed Western European countries. France, Sweden, England and Austria are all ahead of Hungary regarding the rate of emigration. However, since these countries have a continuous supply of human resources due to substantial immigration, emigration does not make a serious problem for them. On the other hand, even a more modest emigration rate can cause serious concern in Hungary, as population loss caused by emigration is exacerbated by an aging population which is not compensated by immigration.

Previous research results already showed that the intensity of emigration continuously grew in Hungary, especially among highly educated people (SiK, E. 1999; LANGER-RÉDEI, M. et al. 2011; Blaskó, Zs. et al. 2014; BLAsKó, Zs. and GöDri, I. 2014; Dabasi Halász, Zs. and HegYi KéRI, Á. 2015; Molnár, J. et al. 2015; Hárs. Á. 2016). In the case of the six main destination countries (USA, Canada, Australia, Germany, United Kingdom and France) the number of emigrants exceeded 100,000 in 2000 (Egedy, T and Kovács, Z. 2011). Recently, the number of migrants has multiplied. While before 2007 3,000-4,000 people left Hungary annually, in 2008 this figure jumped to 9,500 and since then it has been growing steadily. The increase became more and more dramatic, while in 2011 a total of 15,100 Hungarians moved abroad, in 2012 this figure was already 22,800 and in 2013 it went up to 34,691 . We must also note that these figures are the offi- 
cial data of EUROSTAT, and they are likely to be under-represented because of the difficulty of measuring migration. Thus, the number of Hungarians who live, work or study abroad is probably higher.

\section{Measuring migration intentions, research method and data}

The measurement of international migration is not an easy task. Due to the expansion of the EU and the Schengen Area the registration of migrants became more and more difficult, because neither passport, nor visa is required to cross international borders anymore. It is also problematic that international migration statistics focus exclusively on quantitative issues, and they do not deal with the characteristics of migrants. However, it is necessary to understand the process and the motivations of participants, in order to find policy responses for the negative effects associated with it.

In the light of these it is easy to understand that more emphasis should be placed on measuring migration intentions and estimating future migration flows. Of course, we can try to outline future trends with analysis of time-series data, but based on recent experiences, there could be a lot of unforeseen variables which affect the process and question the reliability of the method. In addition, if the basic data are just estimated or there is some inaccuracy, the future trend calculated from these data could differ from reality. Therefore, we have decided to use empirical research method (i.e. questionnaire survey) to measure the emigration intentions of Hungarians. This method helped us not only to estimate the level of emigration in the near future, but we also got information about the reasons and motivations. In addition, the questionnaire survey shed light on the role of subjective factors (e.g. happiness and satisfaction), which allowed us to find out if subjective or objective quality of life factors have more influence on migration intentions in Hungary.

To meet the challenges of representative data it is important to achieve a high number of respondents. During the combination of field survey and online questionnaire survey finally we received nearly 10,000 filled forms. Due to the large number of respondents, the limited human resources and time, we had to make the fieldwork as efficient as possible. The easiest way was to keep the questionnaire as short and concise as possible. To fill out the questionnaire it took about $2-5$ minutes on average. Before the survey dozens of test questionnaires were filled out by persons also with or without relevant professional experience of surveying. According to the original plan, a random generator selected the sample areas where surveys would have taken place on site. Given the fact that international migration affects mainly urban residents, and more than a third of Hungary's population lives in the county seats, we decided that only these cities were subject to random selection. It also seemed to be a good decision, because during the field surveys we could easily find people in the county seats, who live in the county but not in the seat (i.e. main centre), ensuring balanced spatial distribution. During the field survey we collected a total of 6,461completed questionnaires.

In order to reach the appropriate response rate at the national level (one respondents per thousand people), we also launched an online questionnaire survey. During the design we took into consideration that young people are the most affected by emigration in Hungary (SAnsum-Molnár, J. 2012), therefore, the online questionnaire was sent out mainly to higher education institutions. Finally, a total of 3,372 filled questionnaires were received through the online survey. Thus, the total number of respondents in our sample was 9,833, which provided a solid basis for deeper analysis.

\section{Main findings of research}

\section{Emigration intentions by gender and age}

Due to the size and nation-wide coverage of the sample the representativeness of our data can be considered high. Also, during 
the sampling the group of university and college students was paid special attention, and they are slightly over-represented. The measurement of the emigration intentions of students is really a crucial issue because the loss caused by the emigration of young people, whether it is a short or long-term stay, or permanent move, has an immediate impact on the economy and society (SISKA-SzILASI, B. et al. 2016).

In terms of gender distribution women are slightly overrepresented (ration of female respondent was $55.2 \%$ ) in our sample. The intention of women to emigrate is higher than to that of the men, thus, our results also confirm previous research results (GöDRI, I. 2005) that the earlier dominance of men in international migration has mostly disappeared by now (Figure 1).

The relatively high willingness of women to emigrate from Hungary can be explained by several factors. Firstly, the growing employment level of women which causes the prolongation of starting a family and having children plays clearly a role. Secondly, cultural and social factors (globalisation) also influence the growing participation of women in emigration. Nowadays the family and the society accept the higher mobility of women which gives them more freedom in decisions regarding emigration.

Due to the method of sampling younger age groups were overrepresented among respondents. 76 percent of them belonged to the age group 13-40 years. As Figure 2 shows, the propensity for migration among younger peo-

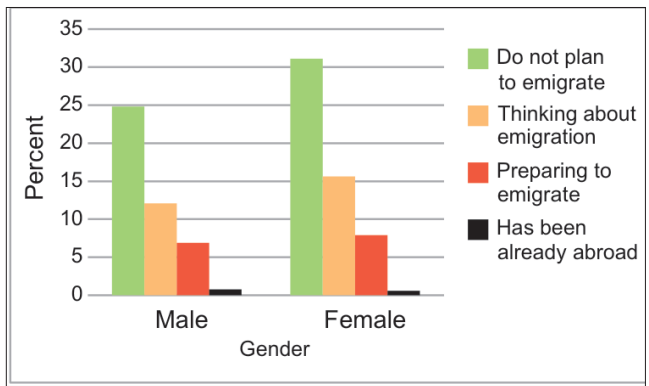

Fig. 1. Emigration intentions by gender. Source: own survey ple is higher, for the age group below 40 the overall emigration propensity is 52.3 percent, whereas in the age group over 40 the ratio drops to 17 percent. This is in line with earlier research findings on Hungarian emigration (SEEMIG 2014). We can find sharp differences between the two main age groups (below and above 40) also regarding concrete migrations plans and previous experiences. In the younger age group (those below 40) the ratio of those who plan to move abroad within one year is 18 percent, whereas in the older age group (those above 40 ) it is only 4.5 percent. Previous migration experiences do not show substantial differences. 1.5 per cent of the younger cohort had already lived abroad while it was only 1.1 percent among those above 40 .

\section{The geography of emigration intentions}

Due to the sampling method we could aggregate answers of respondents (according to the places of residence) for 38 geographical units within Hungary, among them 19 counties, 18 county seats (i.e. major cities) and the capital Budapest. To measure the intensity of emigration intentions we created a new index, which shows the weighted emigration intentions of people. The Emigration Intention Index (EMINI) was calculated as follows:

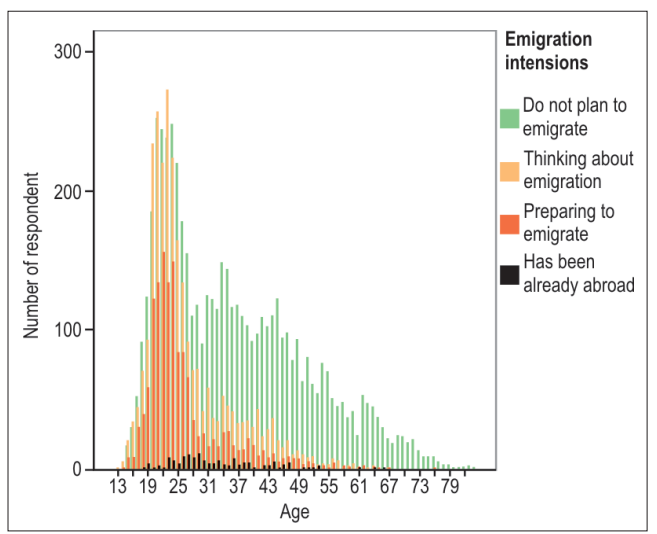

Fig. 2. Emigration intentions by age. Source: own survey 


$$
\text { EMINI }=\frac{(0,25 * T h)+(0,5 * \text { Pre })+(1 * L a)}{N_{\text {resp }}} * 100
$$

where $T h=$ Thinking about emigration, Pre $=$ Preparing to emigrate, $L a=$ Living abroad and $N_{\text {resp }}=$ Number of respondents

The EMINI index could help us define the relative strength of emigration intentions by counties and major cities in Hungary. The pattern shown by Figure 3 is somewhat different from the classic East-West dichotomy, which is otherwise very characteristic for Hungary. Three counties with the lowest emigration intentions (Pest, Jász-NagykunSzolnok and Hajdú-Bihar counties) are located around Budapest and in the eastern part of the country. Highest EMINI values were found in the north (Nógrád, Heves and Borsod-Abaúj-Zemplén counties), in the southern Transdanubia (Baranya county) and along the Austrian border (Vas and GyőrMoson-Sopron counties). The first group of high EMINI values covers those counties that suffered most from economic restructuring and the loss of industrial jobs over the last two decades. On the other hand, counties along the Austrian border belong to the most developed part of the country, with low level of unemployment and higher average wages. Yet, the proximity of Austria and Germany with much higher salaries creates a significant triggering factor for local labour force.

In most cases cities (i.e. county seats) showed lower level of relative emigration intentions than their hinterland. The value of EMINI index was highest in the major centres of Eastern Hungary: Miskolc, Nyíregyháza, Debrecen, Szolnok and in Budapest. In the case of Budapest the role of global information flows and the higher educational level of population are also undeniable. The EMINI index also shed light on interesting ruralurban dichotomy. Generally, people living in rural areas showed much less intentions to emigrate than urban people. In this case the role of place attachment and the strong retaining function of family and local social networks seem to be relevant.

The analysis of push factors behind the emigration intentions was also important part of our research. Figure 4 illustrates the main push factors for counties merged into broader categories. The most important group with

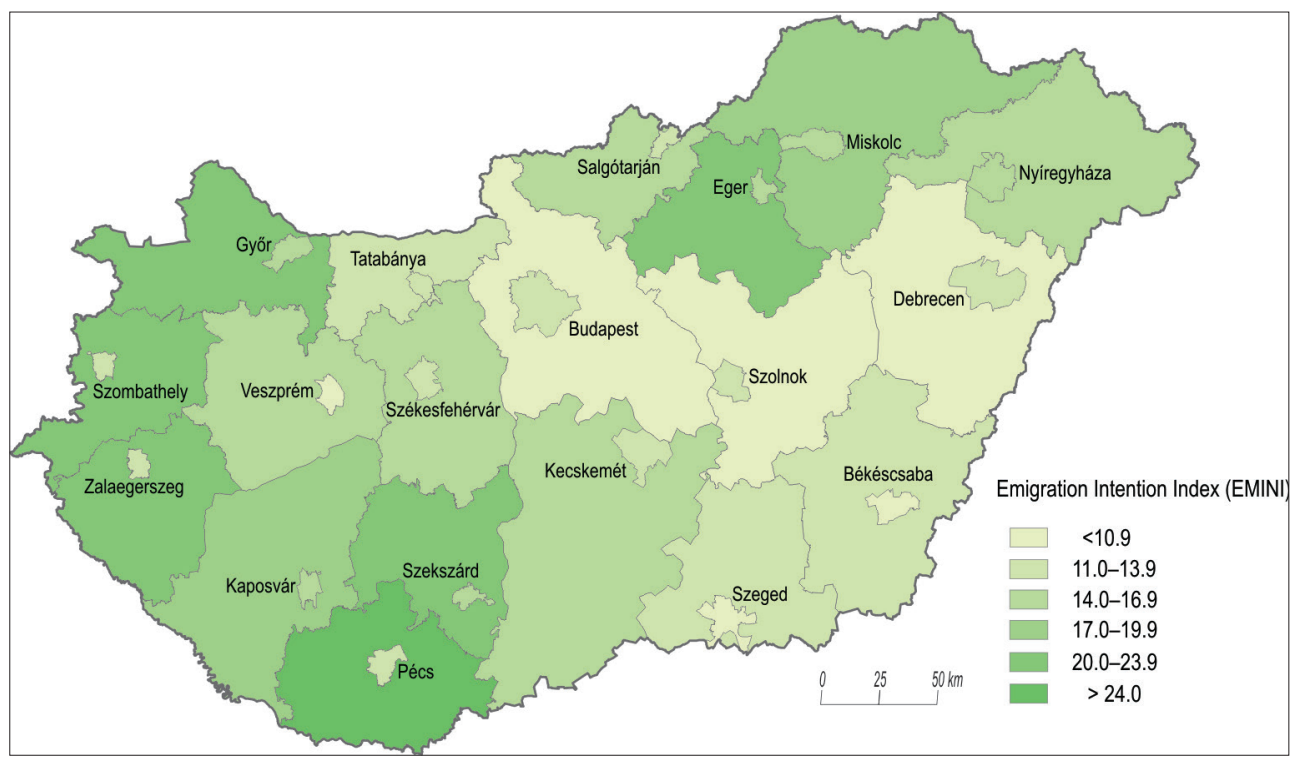

Fig. 3. Emigration Intention Index (EMINI) by counties and cities in Hungary. Source: own survey and calculation 


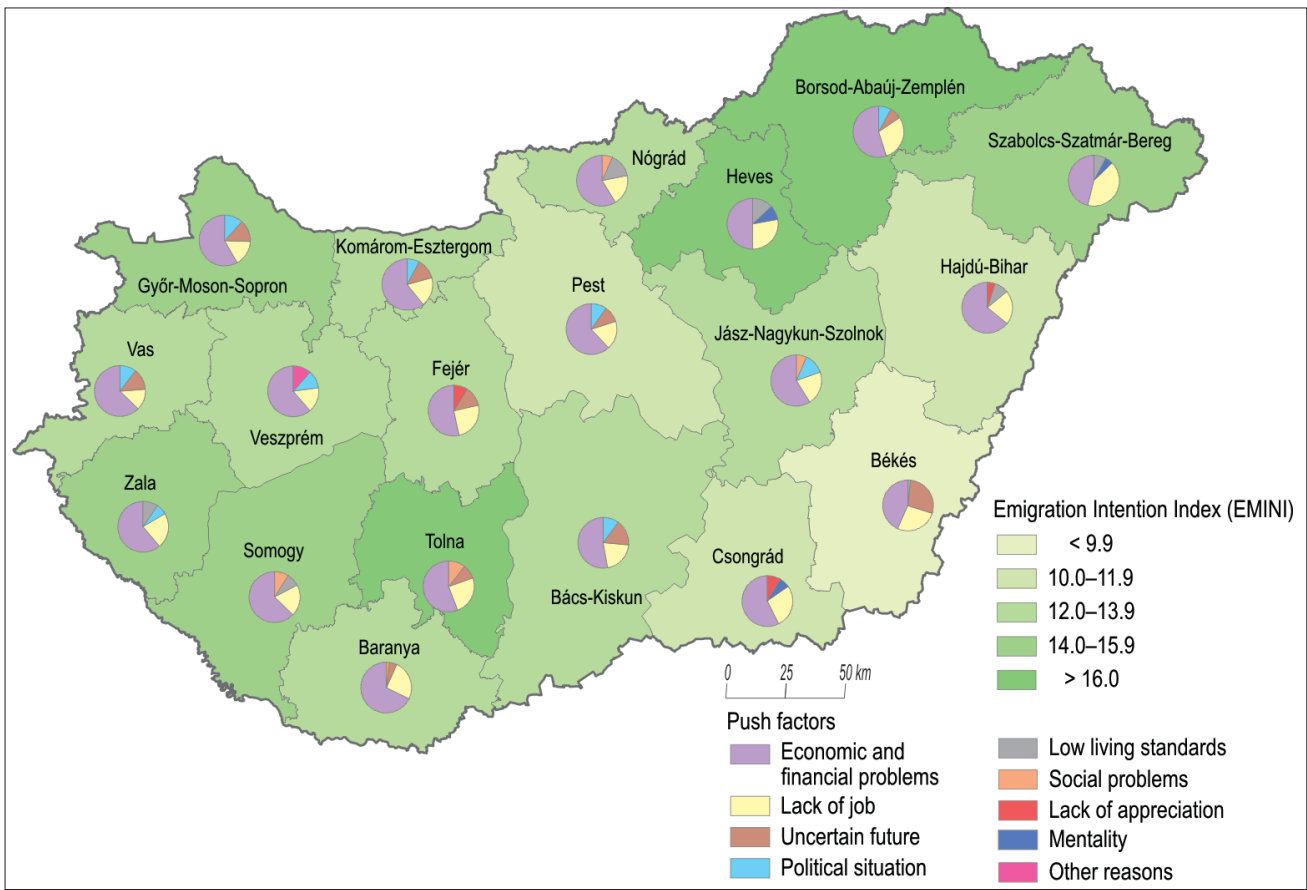

Fig. 4. Distribution of EMINI, with the main push factors in Hungary. Source: own survey and calculation

29 percent of the answers referred to "economic and financial problems".

The second most important push factor was "lack of jobs" with 13.6 percent of the answers. Future uncertainties (mostly financial) were handled as a separate category and covered 5.2 percent of the answers. Thus, we can say that answers related to economic difficulties and uncertainties made up nearly fifty per cent of the total answers regarding push factors. Other factors like political situation $(5.3 \%)$, "low living standards" (3.9\%), "lack of appreciation" (3.0\%) had much less influence. Answers categorised as "social problems" included discrimination, cultural problems, minority problems, bureaucracy. The weight of this group was also relatively low with 3.1 percent of the answers. In the group of "other reasons" answers were included like: do not like the country, lack of experience, frustration, privacy problems, unhappiness, fear, lack of recreational opportunities. However, their role was negligible.
If we examine counties with highest EMINI values and their push factors we can see that the role of economic and financial problems as push factors is everywhere outstanding. Special case is Békés county where the weight of economic factors is low, however, uncertain future appears with a higher than average weight.

Important agents of emigration are friends and relatives who are already living abroad and who can help potential migrants to find a job and housing in the target country, who can assist in arranging bureaucratic affairs or even in integration as well. Figure 5 shows the distribution of those who have intentions to emigrate or has been living abroad according to two major categories whether they have contacts abroad or not. The results are not so much astonishing people with contacts abroad have higher share among potential migrants than the mainstream population. However, a very important trend was shown by our results, due to increasing emigration rates there 


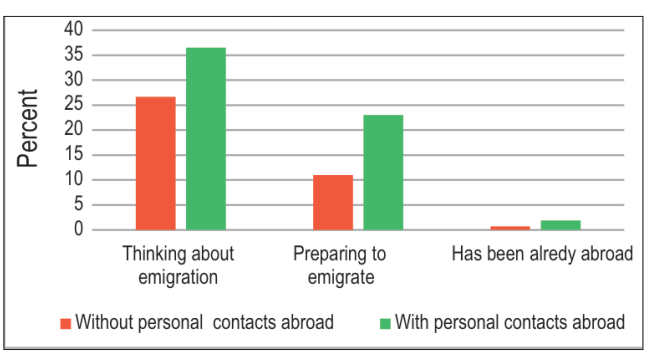

Fig 5. Relation between emigration intention and having contacts abroad. Source: own survey

are more and more people who have acquaintances abroad. This trend makes the hypothesis on further accelerating emigration very likely, due to intensifying personal relations.

\section{Conclusions and future research questions}

The free movement of people principle within the European Union has left its imprints on the Hungarian labour market and economy since 2004. A significant part of the active population has decided to work abroad after taking into account various factors. In our research the emigration intentions of the Hungarian population was investigated, with special focus on the main triggering factors of the process.

As part of the research we carried out a questionnaire survey among Hungarian people (both on site and online) which created a unique data base. The survey focused primarily on the emigration intentions of people. Our data showed that the main destination countries for Hungarians are still Germany, the UK, Austria and the USA. We pointed out marked territorial differences within the country regarding emigration intentions. Based on our empirical research, the following findings can be summarised:

- The main reasons behind the emigration intentions of Hungarians are the economic situation of the country and unsatisfactory job opportunities. Uncertain future, corruption and people's mentality are also among the push factors, but with less relevance.
- The level of emigration intentions is somewhat higher for women than men which are the outcomes of growing employment and career opportunities of ladies. This is clearly a break with the state-socialist past when males were much more mobile than female.

- The intention to move is much stronger among people of the young active age groups (i.e. below 40). This is not surprising and it can be explained with better language skills and less family ties among young people.

- The Emigration Intention Index (EMINI) proved to be a useful indicator showing emigration intentions of people living in different geographical areas. We calculated EMINI values for counties, county seats (i.e. bigger cities) and other settlements. According to our data the classic East-West dimension of emigration intentions within Hungary has changed, Budapest and regions located in the west are also heavily affected by international migration, just like former mining and industrial regions and agricultural areas with serious economic problems.

- The growing importance of personal networks in emigration was also confirmed. Information and help provided by friends and relatives who live or had been living abroad has utmost importance in current migration decisions.

We plan to continue this research with investigating Hungarian migrants who actually live abroad. For this purpose an online questionnaire survey has been launched which aims to collect information about the Hungarian communities living abroad. Besides, using the snowball method we also try to extend our survey with interviewing Hungarians living abroad, and also some of those who have already returned to Hungary. We think that migration (both emigration and return migration) will remain a hot issue in Hungary and other post-socialist countries; therefore, the topic deserves increased attention among geographers.

Acknowledgement: This research was supported by the Hungarian Scientific Research Fund (OTKA) Grant No. 109449. 


\section{REFERENCES}

Blaskó, Zs and GöDRI, I. 2014. A munkaerőpiaci kivándorlás Magyarországról; szelekció- és célország-választás az „új migránsok" körében (The emmigration from the labour market of Hungary; selection and choice of target country among the "new migrants"). Demográfia 57. (4): 271-307.

Blaskó, Zs., Ligeti, A.S. and Sík, E. 2014. Magyarok külföldön - Mennyien? Kik? Hol? (Hungarians abroad - How many? Who? Where?). In Társadalmi Riport 2014. Eds.: Kolosi, T. and Tóтн, I.Gy., Budapest, TÁRKI, 351-372.

Dabasi Halász, Zs. and Hegyi Kéri, Á. 2015: „Fel/ eltörekvő" generáció migrációja Miskolcon (“Up start" generation migration of Miskolc). Északmagyarországi Stratégiai Füzetek 12. (1): 17-26.

Dayton-johnson, J., Pfeiffer, A., Schuettler, K. and Schwinn, J. 2009. Migration and Employment. In Employment is the Mayor Route out of Powerty - How Donors can Help? Background Papers. Paris, DCD/ DAC, OECD, 149-177.

Egedy, T. and Kovács, Z. 2011. Budapest as a destination of migration: the view of transnatonal creative workers. Hungarian Geographical Bulletin 60. (2): 161-188.

GöDRI, I. 2005. Nők és férfiak a migrációs folyamat különböző szakaszaiban. A magyarországi bevándorlás a nemek perspektívájából (Women and men are at various stages of the migration process. The Hungarian immigration from the gender perspective). In Szerepváltozások. Jelentés a nók és férfiak helyzetéról. Eds.: NAGY, I., Pongrácz, T-NÉ, and TóTH, I.Gy., Budapest, TÁRKI - Ifjúsági, Családügyi, Szociális és Esélyegyenlőségi Minisztérium, 149-164.

Hárs, Á. 2016. A munkaerópiaci elvándorlás, bevándorlás és a magyar munkaerốpiac. Jelenségek, hatások, lehetöségek (The Hungarian labour market and its emmigration and immigration processes. Phenomena, impacts and possibilities). Budapest, TÁRKI. www.tarki.hu/hu/publi cations/ SR /2016/12hars.pdf

HidasI, J. 2011. Migráció és mobilitás (Migration and mobility). In Tanulmányok a nemzetközi migráció köréból. Ed.: NyuszTay, L., Budapest, Perfekt Gazdasági Tanácsadó, 44-56.

ILLés, S. 2008. Indirect estimation on the types of international elderly migration in Hungary. Romanian Review on Political Geography 8. (1): 55-63.

LAKatos-Báldy, Zs. 2011. Válság, kulturális diverzitás, migráció - egy nemzetközi konferencia tükrében (Crisis, cultural diversity and migration - in the light of an international conference). In Tanulmányok a nemzetközi migráció köréból. Ed.: Nyusztay, L., Budapest, Perfekt Gazdasági Tanácsadó, 189-203.

Langer-Rédei, M., Illés, S., Karácsonyi, D. and KINCSES, Á. 2011. Ukrán állampolgárok Magyarországon
(Ukrainian citizens in Hungary). Budapest, Európai Integrációs Alap.

Marien, A. 2015. A területi identitás magatartási megnyilvánulásai, különös tekintettel a költözési szándékra és annak magyarázatára (The behavioural manifestations of the regional identity, especially the explanation of the migrational intention). Észak-magyarországi Stratégiai Füzetek 12. (1): 4-16.

Molnár, J., Gál-Szabó, L., Siska-Szilasi, B., Vadnai, P., Moнos, M. and Dudás, G. 2015. Legújabb trendek a magyarországi kivándorlásban (Recent trends in Hungarian emigration). Észak-magyarországi Stratégiai Füzetek 12. (1): 27-37.

NyÁradi, G. 2011. Tudástranszfer és kooperáció a migrációkutatásban (Knowledge transfer and cooperation in the migration research). In Tanulmányok a nemzetközi migráció köréből. Ed.: NyuszTaY, L., Budapest, Perfekt Gazdasági Tanácsadó, 175-188.

Portes, A. and Böröcz, J. 1989. Contemporary Immigration: Theoretical Perspectives on its Determinants and Modes of Incorporation. International Migration Review 23. (3): Special Silver Anniversary Issue, 606-630.

Robila, M. 2010. Eastern European Immigrant Families. New York-London, Routledge.

RoHR, A. 2012. Kivándorlási, külföldi munkavállalási tervek a PTE hallgatóinak körében (The plans of emigration and working abroad of the students of University of Pécs). Acta Sociologica 5. 181-190.

SALT, J. 2001. Current trends in international migration in Europe. Strasbourg, Council of Europe, CDMG 33.

SANSUM-MolnÁr, J. 2012. A külföldi munkavállalás lehetősége a magyar felsőoktatásban tanulók terveiben (The possibility of working abroad in the future plans of Hungarian students). In VI. Magyar Földrajzi Konferencia Tanulmánykötete, Szeged, Szegedi Tudományegyetem, 618-627.

SEEMIG 2014. Helyzetkép a magyarországi elvándorlásról (Emigration status report of Hungary). SEEMIG Managing Migration in South East Europe Project, Press copy. Budapest, KSH.

Sík, E. 1999. Migrációs potenciál a mai Magyarországon. A munkaerő migrációja és az Európai Unió (The migration potential in the present Hungary. The workforce migration and the European Union). Európai Tükör 61. 93-118.

Siska-Szilasi, B., Kóródi, T. and Vadnai, P. 2016. Menni vagy maradni? Egyetemisták kivándorlási szándékának statisztikai vizsgálata (Staying or leaving? The statistical analysis of the emmigration intention of the university students). In Social Geographical Challenges and Search for Adequate Answers in East-Central Europe of the 21 ${ }^{\text {st }}$ Century. Eds.: Berghauer, S. et al., Berehove, International Geographical Conference, UA, 211-218.

Szabó, A. 2015. Az egyetemisták és föiskolások Magyarországon (University and college students in Hungary). Szeged, Belvedere Meridionale. 